\title{
The role of anti-phospholipid antibodies in autoimmune reproductive failure
}

\author{
Priyadarshini Pantham¹, Vikki M Abrahams² and Lawrence W Chamley ${ }^{3}$ \\ ${ }^{1}$ Section of Neonatology, Department of Pediatrics, University of Colorado Anschutz Medical Campus, Aurora, \\ Colorado, USA, ${ }^{2}$ Department of Obstetrics, Gynecology and Reproductive Sciences, Yale School of Medicine, \\ New Haven, Connecticut, USA and ${ }^{3}$ Department of Obstetrics and Gynaecology, University of Auckland, \\ Auckland, New Zealand
}

Correspondence should be addressed to P Pantham; Email: priyadarshini.pantham@ucdenver.edu

\begin{abstract}
Anti-phospholipid antibodies (aPL) are autoantibodies that are associated with thrombosis and a range of pregnancy complications including recurrent pregnancy loss and pre-eclampsia. The three clinically relevant, well-characterized aPL are anti-cardiolipin antibodies, lupus anticoagulant and anti-beta-2-glycoprotein I $\left(\beta_{2} \mathrm{GPI}\right)$ antibodies. aPL do not bind directly to phospholipids but instead bind to a plasma-binding 'cofactor'. The most extensively studied cofactor is $\beta_{2} \mathrm{GPI}$, whose role in pregnancy is not fully elucidated. Although the pathogenicity of aPL in recurrent pregnancy loss is well established in humans and animal models, the association of aPL with infertility does not appear to be causative. aPL may exert their detrimental effects during pregnancy by directly binding trophoblast cells of the placenta, altering trophoblast signalling, proliferation, invasion and secretion of hormones and cytokines, and by increasing apoptosis. Heparin is commonly used to treat pregnant women with aPL; however, as thrombotic events do not occur in the placentae of all women with aPL, it may exert a protective effect by preventing the binding of aPL to $\beta_{2} \mathrm{GPI}$ or by acting through non-thrombotic pathways. The aim of this review is to present evidence summarizing the current understanding of this field.

Reproduction (2016) 151 R79-R90
\end{abstract}

\section{Anti-phospholipid antibodies: introduction and background}

Anti-phospholipid antibodies (aPL) comprise a heterogeneous family of autoantibodies that are associated with thrombosis and pregnancy mortality, particularly recurrent pregnancy loss. There are three clinically relevant aPL: i) lupus anticoagulants (LA) that are detected in serum using in vitro coagulation assays; ii) anti-cardiolipin antibodies $(\mathrm{aCL})$ that are detected in serum or plasma by ELISA and iii) anti-beta-2-glycoprotein I $\left(\beta_{2} \mathrm{GPI}\right)$ antibodies, which are also detected in serum or plasma by ELISA. Although ELISA is the most common method of detection of $\mathrm{aCL}$ and anti- $\beta_{2} \mathrm{GPI}$ antibodies, other methods such as RIA, fluoro-enzyme immunoassay, multiplexed immunoassay and chemiluminescent immunoassay may also be used to detect aPL positivity (Forastiero et al. 2014). Laboratory criteria for the detection of aPL require detection of $\mathrm{LA}, \mathrm{aCL}$ or anti$\beta_{2} \mathrm{GPI}$ on two or more occasions at least 12 weeks apart (Miyakis et al. 2006). It is necessary to conduct repeat tests as some infections are associated with transient false-positive results, especially in aCL tests.

Historically, aPL were first identified in patients with biologically false-positive tests for syphilis (Asherson
\& Cervera 1993). These patients were found to have autoantibodies that produced a false-positive syphilitic 'reagin' test and the antigen in the reagin test is the negatively charged phospholipid, cardiolipin (Pangborn 1941). LA were initially identified in patients with the autoimmune disease systemic lupus erythematosus (SLE). LA were also found to be autoantibodies that reacted with negatively charged phospholipids, and in doing so prolonged the in vitro clotting time in phospholipid-dependent coagulation assays, such as the activated partial thromboplastin time and the dilute Russel Viper Venom time. Paradoxically, in vivo, LA are associated with thrombotic disease (Love \& Santoro 1990, Galarza-Maldonado et al. 2012). Historically, it was noted that several patients with LA also had biologically false-positive tests for syphilis, suggesting that these may be the same autoantibodies. In an attempt to improve the clinical utility and efficiency for these two aPL tests, solid-phase immunnoassays (especially ELISAs) using cardiolipin as the antigen were produced. Some but not all LAs also demonstrate $\mathrm{aCL}$ activity and vice versa. Although the traditional view was that aPL bind to negatively charged anionic phospholipids, it is evident that the term 'antiphospholipid antibodies' is a misnomer, and aPL 
do not bind directly to phospholipids, but rather to a complex containing a negatively charged phospholipid and a phospholipid-binding 'cofactor' (Mclntyre et al. 1997, de Laat et al. 2004, 2007). The most widely studied of these cofactors is $\beta_{2} \mathrm{GPI}$. Indeed, it has been shown that many, but not all, autoantibodies that are detected in anti-cardiolipin ELISAs can react directly with $\beta_{2} \mathrm{GPI}$, in the absence of phospholipid, provided that a suitable negatively charged surface is available to immobilize the $\beta_{2}$ GPI. Immobilization of the $\beta_{2} \mathrm{GPI}$ on such a surface facilitates the binding of $\mathrm{APL}$ in one of two ways: either binding to the negative surface induces a conformational change in the protein that facilitates binding of aPL to a previously hidden cryptic epitope or the negative surface allows clustering of the $\beta_{2} \mathrm{GPI}$ that facilitates high-affinity binding of aPL or a combination of these two mechanisms (Fig. 1).

The relationship between LAs, aCL and anti- $\beta_{2} \mathrm{GPI}$ antibodies varies between patients and specific clones of antibody. Patients may have only one of the three $\mathrm{aPL}$, or any combination of two or three of them, and the relative importance of these three antibodies is not always clear. However, there is growing acceptance that LAs are strongly correlated with disease and that patients who are positive for all three aPL are at the most risk of disease (Ruffatti et al. 2011, Galli 2012, Roggenbuck et al. 2012). LA correlates better with thrombosis, pregnancy morbidity and thrombosis in SLE than do aCL. Detection of LA in a patient with SLE predicts a $50 \%$ chance of a thrombotic event over 20 years follow-up. IgG/lgM isotype aCL antibodies, but especially those of the $\lg$ isotype, are frequently associated with thrombosis and pregnancy failure.

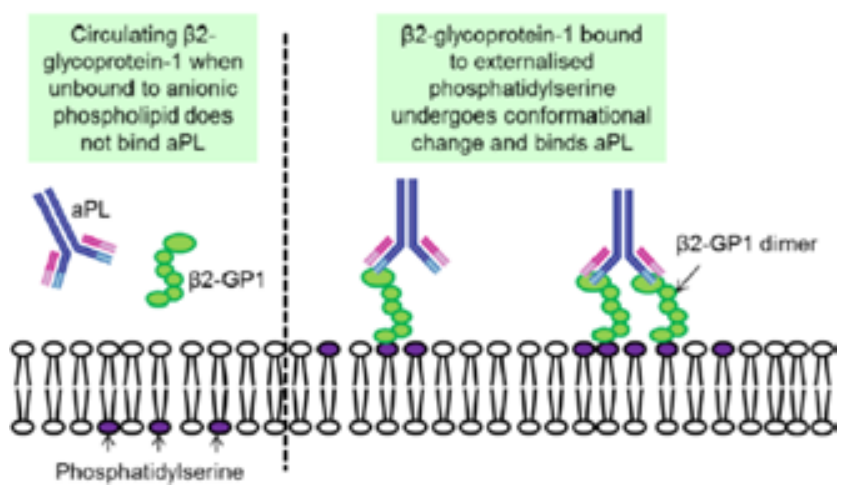

Figure 1 The antigenicity of anti-phospholipid antibodies (aPL). aPL bind to $\beta_{2}$ GPI but only when this protein is immobilized on a suitable negatively charged surface. Such surfaces include the negatively charged phospholipids, cardiolipin and phosphatidylserine. Irradiated polystyrene, as found in many high-protein-binding ELISA plates is also a suitable negatively charged surface. In the circulation, in vivo, high levels of both aPL and $\beta_{2} \mathrm{GPI}$ can coexist, as the circulating $\beta_{2} \mathrm{GPI}$ is not antigenic for aPL. If negatively charged

phosphatidylserine becomes exposed to the circulation, for example after an injury, $\beta_{2} \mathrm{GPI}$ can bind to the phosphatidylserine and becomes antigenic for aPL either by exposing a cryptic epitope or via antigen-clustering (or a combination of the two).
A recent systematic review indicated that $\lg \mathrm{G}$ isotype $\mathrm{aCL}$ were approximately four times more prevalent than IgM isotype $\mathrm{aCL}$ in patients with anti-phospholipid antibody syndrome (APS; Rodriguez-Garcia et al. 2015). This review also suggests that IgA isotype aCL are relatively common in patients with APS $(20 \%)$ and that IgA isotype anti- $\beta_{2} \mathrm{GPI}$ antibodies were even more common in these patients (56\%). IgG and IgM anti- $\beta_{2}$ GPI are independent risk factors for thrombosis and pregnancy complications (Miyakis et al. 2006).

\section{The APS}

With the increased availability of simple tests, it became apparent that aPL identified a subset of patients with SLE who had either thrombotic disease, pregnancy complications or both. It also became apparent that there were a large number of patients, especially women with pregnancy complications, who had aPL but did not have a defined autoimmune disease or systemic thrombotic disease. Consequently, the APS was defined to describe patients with one or more aPL in the presence of thrombotic disease and/or pregnancy morbidity. The first criteria for classification of APS were developed in Sapporo, Japan, in 1990 and are referred to as the 'Sapporo criteria'. These criteria were revised in 2006 at the Eleventh International Congress of Antiphospholipid Antibodies, and these revised Sapporo criteria remain the most recent international consensus for the diagnosis of APS (Miyakis et al. 2006). Patients can have primary APS in the absence of other disease, or APS secondary to SLE or other pre-existing autoimmune conditions.

\section{Anti- $\beta_{2}$ GPI antibodies}

In recent years in an attempt to improve the diagnostic specificity of aPL testing, there has been a focus on attempting to define specific epitopes within $\beta_{2} \mathrm{GPI}$ with which disease-causing pathogenic antibodies react. Structurally, $\beta_{2}$ GPI contains five domains of $\sim 60$ amino acids that are referred to as short consensus repeats (SCRs) or sushi domains. It has been suggested that the first SCR domain (domain 1) contains an epitope with which particularly pathogenic aPL react (Iverson et al. 1998, de Laat et al. 2009). An international multicentre evaluation of 477 patients established that a strong association existed between anti- $\beta_{2} \mathrm{GPI}$-domain I antibodies and venous thrombosis, and to a lesser extent pregnancy complications (de Laat et al. 2009). In another recent study, Andreoli et al. evaluated the domain specificity profile of anti- $\beta_{2} \mathrm{GPI}$ antibodies in 159 subjects with persistently positive-, medium- or high-titre anti- $\beta_{2} \mathrm{GPI}$ IgG. The prevalence of anti- $\beta_{2}$ GPI domain 1 antibodies was $73 \%$ in patients with thrombosis, and $64 \%$ in patients with obstetric APS. Anti-domain 4 and 5 antibodies were present in $19 \%$ and $16 \%$ of thrombotic and obstetric APS respectively (Andreoli et al. 2015). Although it is 
clear that anti-domain 1 antibodies are important in the pathogenesis of the systemic thrombotic manifestation of APS, it is much less clear that these antibodies have a particular role in obstetric APS (de Jesus et al. 2014). It is abundantly clear that many women with obstetric as well as other complications of the APS have antibodies that react with other SCR domains of $\beta_{2}$ GPI (de Jesus et al. 2014, Poulton et al. 2015).

\section{Non-consensus aPL}

It is important to acknowledge that other autoantibodies that recognise negatively charged phospholipids or phospholipid-binding proteins, including antibodies against phosphatidylserine, phosphatidylinositol and phosphatidic acid, the zwitterionic phospholipid phosphatidylethanolamine, or the proteins annexin $\mathrm{V}$, protein $\mathrm{C}$, protein $\mathrm{S}$, thrombomodulin and oxidised LDL, have been reported (Gharavi et al. 1987, Oosting et al. 1993, Horkko et al. 1996, Rand et al. 1998, Atsumi et al. 2000, Miyakis et al. 2006, Hirakawa et al. 2012). As phosphatidylserine, such as cardiolipin, is a negatively charged phospholipid, it can also bind to $\beta_{2} \mathrm{GPI}$, as does oxidised LDL, and it is possible that at least some of the non-consensus aPL are the result of cross-reactive antibodies that will behave as anti- $\beta_{2} \mathrm{GPI}$ or aCL or anti phosphatidylserine (Wu et al. 1999). Although all these antibodies may be related to $\mathrm{APL}$, they are not included in the consensus criteria for the diagnosis of APS because their clinical significance is unclear (Bertolaccini et al. 2011).

\section{aPL and obstetric diseases}

Estimates of the prevalence of aPL in the general obstetric population range from 1 to $7 \%$ (Faden et al. 1997); however, most estimates are closer to $1-2 \%$. In contrast, aPL have been reported to be more common in women with stillbirths, recurrent miscarriages, pre-eclampsia and intrauterine growth restriction (IUGR). Approximately $7-25 \%$ of unexplained recurrent miscarriage may be due to the presence of aPL (Drakeley et al. 1998) along with $3.8 \%$ of stillbirths and $13.7 \%$ of IUGR (Silver et al. 2013, Cervera et al. 2015). The reported occurrence of $\mathrm{aPL}$ in pre-eclampsia is highly variable, ranging from $11 \%$ to $61 \%$ (Branch et al. 1989, Yasuda et al. 1995, Katano et al. 1996); however, one group has shown that $\mathrm{aPL}$ are one of the strongest maternal risk factors for developing pre-eclampsia, increasing a woman's risk approximately ten-fold (Duckitt \& Harrington 2005).

The revised Sapporo criteria define the obstetric manifestations of APS as follows: i) the occurrence of recurrent spontaneous abortion (miscarriage) before the tenth week of gestation, ii) unexplained fetal loss after the tenth week of gestation or iii) the development of pre-eclampsia/eclampsia or placental insufficiency before the 34th week of gestation (Miyakis et al. 2006).
Recently, the Taskforce on Obstetric Antiphospholipid Syndrome has systematically reviewed the relevant literature and confirmed the association of aPL with these complications of pregnancy (de Jesus et al. 2014).

The first demonstration that aPL are directly pathogenic in pregnancy came in 1990 with the passive transfer of human aPL into pregnant mice (Rote et al. 1990). This resulted in fetal demise, and since then several groups, using either passive transfer of aPL or immunization with $\beta_{2} \mathrm{GPI}$, have confirmed that aPL cause fetal demise and growth restriction equivalent to stillbirth/miscarriage and placental insufficiency using murine models (Bakimer et al. 1992, Blank et al. 1994). Moreover, a role for $\beta_{2} \mathrm{GPI}$ has also been confirmed in the development of aPL-mediated pregnancy loss (Robertson et al. 2004). Until recently, whether aPL cause pre-eclampsia, a human pregnancy-specific disease characterized by new-onset hypertension in the second half of pregnancy, had not been demonstrated. However, when pregnant mice are immunized with $\beta_{2} \mathrm{GPI}$, aPL titres increase and the mice exhibit pre-eclampsia-like symptoms such as hypertension and proteinuria (Ding et al. 2014). How aPL cause the pregnancy complications with which they are associated remains unclear. In both women and men, aPL are associated with systemic thrombotic disease, and that aPL can also induce thrombosis has also been demonstrated in animal models where transfer of human aPL to mice results in excess thrombosis, but usually only following an induced vascular insult. It is now very clear that thrombosis is not the primary mechanism by which aPL induce obstetric complications (Viall \& Chamley 2015); although thrombosis may be seen in a small proportion of placentae from late fetal deaths, uteroplacental thrombosis is not a feature of early gestation losses (Viall \& Chamley 2015).

Before the widespread access to the ELISA-type aPL assays, women with these antibodies were usually identified because of a poor obstetric history, specifically late fetal death, which was frequently accompanied by placentae with evidence of extensive infarction (Out et al. 1991). Many, if not most of these, women also had classical autoimmune diseases and systemic thrombotic complications. This finding, coupled with the known association of aPL with thrombotic disease, leads to the reasonable hypothesis that aPL-mediated fetal demise was due to thrombosis in the uterine spiral arteries that supply maternal blood to the placenta, or in the intervillous spaces of the placenta (the original basis for the use of anticoagulant therapies such as heparin and low-dose aspirin (LDA; Ginsberg et al. 1995). However, with easy access to tests for aPL, a large number of women have been identified with aPL who do not have systemic thrombotic disease and whose placentae were not characterized by thrombotic lesions/infarction (Out et al. 1991, Salafia \& Cowchock 1997). This led to the suggestion that obstetric manifestations of APS are not mediated primarily by thrombosis, but rather by direct 
effects of aPL on the trophoblast cells of the placenta. This was further supported by the finding that $\beta_{2} \mathrm{GPI}$ is synthesised by the trophoblast and is thus endogenously localized to the syncytiotrophoblast, cytotrophoblast and extravillous trophoblast populations (Chamley 1997). Indeed, a recent systematic review concluded that only one-third of women with aPL demonstrate signs of uteroplacental thrombosis (Viall \& Chamley 2015).

\section{There is no causative relationship between infertility and $\mathrm{aPL}$}

The incidence of aPL is reported to be 22 and 30\%, respectively, in infertile women and women with recurrent IVF failure (Buckingham \& Chamley 2009). However, due to a lack of well-designed studies, and lack of concordance between antibodies detected in each study, the causative nature of this association has not been established. A systematic review of the literature analysed the association of $\mathrm{aPL}$ and IVF outcome and showed that 13 of 29 studies reported a higher prevalence of aPL in infertile women. However, most of the studies used non-standardized, non-criteria aPL tests. Importantly, the presence of aPL was not found to influence IVF outcome, and treatment of aPL-positive patients undergoing IVF was not found to be beneficial. The Taskforce on Obstetric Antiphospholipid Syndrome also recently reviewed this topic and concluded that there is little evidence that aPL affect negatively on fertility and that infertility should not be included in the criteria for APS (de Jesus et al. 2014).

\section{How do aPL cause pregnancy complications? \\ aPL induce characteristic histologic lesions in the placenta}

If we are to understand how aPL induce pregnancy complications via direct effects on placental trophoblasts, it might be expected that we would have a clearer understanding of the pathologic lesions these antibodies induce in the placenta of affected pregnancies. In the past 30 or so years, there have been a number of small studies reporting histopathologic lesions in placentae from women with $\mathrm{aPL}$; however, there has been no overview of these studies. A recent systematic review of the literature clarified which lesions are associated with $\mathrm{aPL}$ and reported that there is a 'fingerprint' of five common pathologic features in the placentae of women with aPL (Viall \& Chamley 2015). These five lesions are as follows: i) placental infarction (found only in later gestation placentae), ii) impaired remodelling of uterine spiral arteries, iii) decidual inflammation, iv) increased syncytial knots in the syncytiotrophoblast and v) decreased vasculosyncytial membranes (Viall \& Chamley 2015). Thrombotic lesions are not common in the placentae of women with $\mathrm{aPL}$ and were strikingly absent from placentae of early gestational losses, confirming that thrombosis is not a primary pathophysiological mechanism in these pregnancies (Salafia \& Cowchock 1997).

\section{Structure of the human placenta and the role of trophoblasts}

It is now widely accepted that aPL act directly upon trophoblasts of the placenta to induce pregnancy complications in women, and indeed, these antibodies can be eluted from affected placentae (Chamley et al. 1993). The anatomy of the human materno-fetal interface is quite unique and differs significantly from that in commonly used laboratory animals such as rodents. The human placenta has a villous or tree-like branching structure. The body of the human placenta is covered on its maternal-facing aspect by a single multinucleated cell, the syncytiotrophoblast, which is bathed in maternal blood and has a surface area of 11-13 $\mathrm{m}^{2}$ at term (Mayhew 2008). Therefore, the syncytiotrophoblast acts as both a barrier between the maternal and fetal organisms and also the link between the two. The syncytiotrophoblast produces vast quantities of hormones and other factors that are crucial to the success of pregnancy; yet, it is not mitotically active and is formed and replenished by fusion of underlying villous cytotrophoblasts. Growing out from points of contact between the maternal uterine decidua and the villous placenta are columns of extravillous trophoblasts (Fig. 2). The extravillous trophoblasts most proximal to the placenta can proliferate, but as the cells migrate away from the villous surface, they lose their ability to proliferate and instead gain an invasive phenotype. These extravillous trophoblasts migrate into the decidua where they invade and transform the uterine spiral arteries that supply maternal blood to the placenta (Fig. 2). The extravillous trophoblasts erode the musculoelastic walls of the spiral arteries such that these vessels are transformed from narrow-bore resistance arteries to large-diameter tubes that lack the capacity to respond to vaso-constricting stimuli. This transformation of the spiral arteries is necessary to allow the large and uninterrupted supply of maternal blood into the placenta that is required for increasing fetal growth in the later part of pregnancy. As a terminal phase of differentiation, at least some of the extravillous trophoblasts from early gestation form multinucleated placental bed giant cells, the function of which is unknown, but are likely to be important sources of hormones (Pijnenborg et al. 2006). aPL have been reported to affect the function of each of these populations of trophoblasts in vitro.

\section{In vitro effects of aPL on trophoblasts}

Several in vitro studies have been conducted to determine the mechanisms by which aPL interact with 


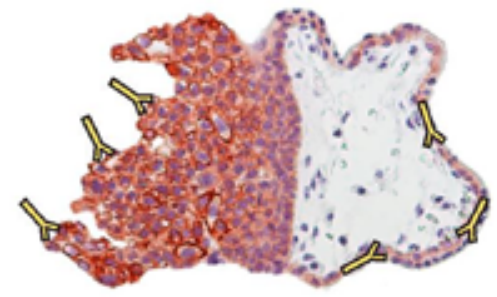

Extravillous trophoblast

Reduced

Invasion

Migration

Proliferation

Spiral artery remodelling

\section{Villous trophoblast}

(Syncytiotrophoblast/cytotrophoblast)

Penetration of syncytiotrophoblast by aPL Decreased mitochondrial function Increased necrotic cell death Increased extrusion of syncytial nuclear aggregates

Reduced proliferation

Reduced hormone production

\section{Altered cytokine production}

Figure 2 Schematic indicating reported effects of anti-phospholipid antibodies on trophoblast. A first-trimester human villous showing interactions of aPL ( $(\boldsymbol{d})$ with both villous and extravillous trophoblasts. Extravillous trophoblast (solid arrows) grows out from anchoring villi into the uterine decidua to transform the spiral arteries allowing increased blood flow to the placenta. The multinucleated syncytiotrophoblast (hollow arrows) covers the entire surface of the placenta and is bathed in maternal blood. The syncytiotrophoblast is a major source of secreted factors, such as hCG and cytokines.

Villous cytotrophoblasts (short arrows) are the proliferating progenitor cells for the syncytiotrophoblast and for the extravillous trophoblasts. Interactions of aPL reduce the various functionalities of each of these different trophoblast subpopulations. As aPL are a heterogeneous family of antibodies, the specific effects of aPL on trophoblasts are likely to be variable depending on the exact mix of epitope specificities and affinities of antibodies present.

and directly affect trophoblast function. These studies were systematically reviewed recently by Tong et al. (2015). That systematic review showed that there is strong in vitro evidence that aPL detrimentally affect trophoblast syncytialization, viability and invasion, and this in vitro data support the lesions seen in the placentae of aPL-affected pregnancies (Viall \& Chamley 2015). Furthermore, aPL also disrupt molecular signalling mechanisms in trophoblasts and increase inflammation and coagulation on the cell surface.

\section{Trophoblast proliferation, migration and invasion}

aPL may negatively affect trophoblast viability and function by reducing proliferation and invasiveness. The majority of studies have examined the effects of polyclonal aPL isolated from patient sera, as well as murine monoclonal aPL on placental explants or cell lines (Yacobi et al. 2002, Ornoy et al. 2003, Bose et al. 2004, Schwartz et al. 2007). Studies examining the mechanism of reduced migration showed that aPL mediate this effect possibly through the downregulation of interleukin 6 (IL6; Mulla et al. 2010) and the up-reguation of TIMP2 (Albert et al. 2014), all

independently of Toll-like receptor 4 (TLR4). Another study, however, has implicated TLR4 in reduced trophoblast migration by aPL (Poulton et al. 2015). More recently, apolipoprotein $\mathrm{E}$ receptor 2 (ApoER2) has been implicated in aPL-reduced trophoblast migration (Ulrich et al. 2016). Others, however, have suggested that aPL binding directly to trophoblasts via adhered $\beta_{2} \mathrm{GPI}$ reduce invasion by altering the repertoire of cell adhesion molecules (Di Simone et al. 2000a, 2002). A consequence of this reduced migratory response has been demonstrated using an in vitro matrigel model of spiral artery transformation. In this system, aPL and sera from APS patients with pregnancy morbidity disrupt the normal trophoblast-endothelial cell interactions (Alvarez et al. 2015).

aPL have also been shown to inhibit the proliferation of trophoblasts and the final differentiation of extravillous trophoblasts into giant multinucleated cells in vitro (Quenby et al. 2005). Reduced proliferation of cytotrophoblasts in response to aPL would have at least two consequences. i) As villous cytotrophoblasts are the proliferating progenitors of the syncytiotrophoblast, reducing the proliferation of villous trophoblasts may limit the growth and repair of the syncytiotrophoblast, resulting in reduced placental transport and barrier functions. ii) Proliferating cytotrophoblasts are also progenitors for extravillous trophoblasts, and thus, reduced trophoblast proliferation would lead to a limited pool of extravillous trophoblasts, resulting in inadequate invasion of the spiral arteries, underperfusion, oxidative stress and ischaemia-reperfusion injury in the placenta. These, in turn, could contribute to the early pregnancy loss, pre-eclampsia and IUGR that are often seen in women with aPL (Tong et al. 2015). The same consequences would result from an aPL-induced reduction in invasiveness of extravillous trophoblasts.

\section{Trophoblast death}

Several in vitro studies have reported an increase in trophoblast death in response to aPL using either term trophoblasts or first-trimester trophoblasts (Di Simone et al. 2001, Yacobi et al. 2002, Ornoy et al. 2003, Schwartz et al. 2007, Chen et al. 2009, Mulla et al. 2009). Cytotrophoblasts isolated from term placentae (Di Simone et al. 2001, 2006) have been shown to alter their expression of the apoptotic regulators Bax and $\mathrm{Bcl} 2$ in response to $\mathrm{aPL}$, but without overt signs of cell death (Di Simone et al. 2006). The final stage in the normal life cycle of the multinucleated syncytiotrophoblast is thought to be that in localised regions, programmed cell death is initiated, followed by the extrusion of proapoptotic or apoptotic nuclei in large multinucleated vesicles called syncytial nuclear aggregates (SNAs; Mayhew 2008, Askelund \& Chamley 2011). These SNAs are then deported via the blood to the maternal lungs where they become trapped in small 
vessels and are cleared, most likely, by pulmonary endothelial cells. There is evidence that aPL alter the nature of cell death in the syncytiotrophoblast to a more necrotic process, evidenced by reduced expression of executioner caspases 3 and 7 (Chen et al. 2012), as well as reduced expression of the protective apoptotic regulator TRAIL in placental explants in response to aPL (Pantham et al. 2012). We have recently demonstrated that aPL are internalized into the syncytiotrophoblast of both first-trimester and term placentae via an antigenspecific receptor-mediated process (Viall et al. 2013). Once inside the syncytiotrophoblast, aPL bind to mitochondria and disrupt mitochondrial function and also induce the release of proapoptotic cytochrome c from the mitochondria (Viall et al. 2013, Pantham et al. 2015a). Consequently, there is an increase in the number of SNAs extruded from the syncytiotrophoblast (Chen et al. 2009, Pantham et al. 2015a). The proteome of SNAs from aPL-treated placentae is altered compared with that of SNAs from control antibody-treated placentae with notable changes in mitochondria-related proteins (Pantham et al. 2015a). In contrast to the SNAs from normal placentae, which prevent the activation of endothelial cells, the SNAs released from aPL-treated first-trimester placentae activate endothelial cells, with the likelihood that the changes in both the number and nature of SNAs contributes to the maternal endothelial cell activation, which is a hallmark of pre-eclampsia (Viall et al. 2013). Metabolomic analysis of the culture media from first-trimester placental explants treated with aPL has demonstrated an increase in ceramide metabolites, which play key roles in cell death by suppressing protein kinase C-epsilon, which is also found to be reduced in response to aPL (Pantham et al. 2015b). It appears likely that aPL alter cell death processes in many if not all trophoblast populations in the human placenta. Increased death in the syncytiotrophoblast is likely to contribute to increased production of SNAs, whereas increased death of extravillous trophoblasts is likely to reduce the pool of these cells available to modify the spiral arteries (Quenby et al. 2005).

\section{Cytokine and hormone production}

The deciduae of women with APS show signs of inflammation (Tong et al. 2015). In vitro studies suggest that aPL may alter the cytokine and hormonal milieu produced by trophoblasts, leading to a pro-inflammatory environment at the maternal-placental interface and altered trophoblast function (Abrahams 2009). It was shown nearly two decades ago that aPL reduce the basal and $\mathrm{GnRH}$-induced production of human chorionic gonadotropin (hCG; Katsuragawa et al. 1997, Di Simone et al. 2000b, Schwartz et al. 2007). Recent evidence suggests that this aPL-mediated reduction in hCG secretion by trophoblasts is mediated via TLR4 (Marchetti et al. 2014). Production of hCG is usually considered to be a marker of syncytiotrophoblast endocrine function, as this cell is the major source of hCG; however, it has been shown that hyperglycosylated hCG can be secreted by, and promotes, extravillous trophoblast invasion (Fournier et al. 2015). Thus, the reductions in hCG secretion induced by aPL may reflect adverse effects of the antibodies on both syncytiotrophoblast and extravillous trophoblast functions. Production of IL3 may be reduced in women with aPL-mediated fetal loss and IL3 has been shown to overcome the inhibitory effects of aPL on trophoblast invasion and hCG secretion, but not trophoblast proliferation (Di Simone et al. 2000a, Chamley et al. 2001). In vitro studies utilizing firsttrimester trophoblasts and murine monoclonal aPL have demonstrated that aPL (both murine $\mathrm{mAb}$ and patientderived $\mathrm{aPL}$ ) increase production of IL8, IL $1 \beta$, monocyte chemotactic protein 1 (MCP1) and GRO $\alpha$ in a TLR4dependent manner. Furthermore, downstream of TLR4, IL $1 \beta$ secretion is mediated by the induction of endogenous uric acid, which in turn activates the Nod-like receptor, Nalp3, leading to Nalp3/ASC/caspase 1 inflammasome activation and subsequent IL $1 \beta$ processing and secretion (Mulla et al. 2013a). These aPL-induced changes could contribute to the reduced placental invasion and proinflammatory profile reported in pregnancies affected by aPL (Abrahams 2009). Reported changes in trophoblast/ placental cytokine production induced by $\mathrm{aPL}$ are summarized in Table 1.

\section{Coagulation}

There has been a considerable amount of research into the mechanisms of coagulation and thrombosis leading to placental infarction due to aPL. aPL may cause coagulation in the proximity of the placenta by reducing the expression of annexin A5 on placental villi (Rand et al. 2006). Annexin A5, also known as placental anticoagulant protein-I and vascular anticoagulant- $\alpha$, is thought to function as a potent anticoagulant by competing with coagulation factors for binding sites on anionic phospholipids such as phosphatidylserine.

Table 1 Reported in vitro effects of aPL on cytokine production by trophoblast/placentae.

\begin{tabular}{|c|c|}
\hline & $\begin{array}{l}\text { Effects of aPL treatment on cytokine } \\
\text { production by trophoblast/placenta in vitro }\end{array}$ \\
\hline Mulla et al. (2009) & $\begin{array}{l}\text { Increased IL8, MCP1, GRO } \alpha \text { and IL } 1 \beta \\
\text { Did not affect IL2, 4, 5, 6, 7, 10, 12, 13, 17, } \\
\text { G-CSF, GM-CSF, IFN } \gamma, \text { MIP1 } \alpha, \text { RANTES and } \\
\text { TNF } \alpha\end{array}$ \\
\hline $\begin{array}{l}\text { Di Simone et al. } \\
(2010)\end{array}$ & Decreased HB-EGF expression \\
\hline Mulla et al. (2010) & Decreased IL6 \\
\hline Carroll et al. (2011) & Increased VEGF, PIGF, sFlt1 and sEnga \\
\hline Ichikawa et al. (2011) & No effect on VEGF or sFlt-1, decreased PIGF \\
\hline Iwasawa et al. (2012) & Increased IL12 \\
\hline Mulla et al. (2013) & Increased IL1 $\beta$ \\
\hline Albert et al. (2014) & Increased TIMP2 \\
\hline
\end{tabular}

affect observed with only one of the two aPL tested. 
Annexin A5 is constitutively expressed on the apical surface of syncytiotrophoblast and may be necessary to maintain vascular homeostasis and blood fluidity, functioning as an 'anticoagulant shield' in the placenta during pregnancy. Disruption of this shield due to aPL has been observed in placental villi from women with APS, as well as in trophoblasts cultured with aPL in vitro (Krikun et al. 1994, Rand \& Wu 1999, Rand et al. 1994, 1997, 1998, 2003, 2004, 2006). It has therefore been postulated that the disruption of the annexin A5 anticoagulant shield in the placenta results in accelerated coagulation and thrombosis at the placental surface, causing recurrent fetal loss and fetal growth restriction in pregnancies with $\mathrm{aPL}$, and this is supported by data from an annexin A5 knockout mouse model (Rand et al. 1994, 2006, Ueki et al. 2012). However, the disruption of the annexin A5 shield is not a universal feature of placentae from pregnancies complicated by aPL (Lakasing et al. 1999). Furthermore, enhanced coagulation at the placental surface is not a common histopathologic feature of pregnancies affected by aPL (Tong et al. 2015), and thus, it is unclear how important disruption of the annexin A5 anticoagulant shield is in the pathogenesis of obstetric APS.

\section{Receptors that mediate the effects of aPL in the placenta}

Although it was originally thought likely that aPL reacted with phospholipids in the cell membrane of target cells, it now seems much more likely that the interaction of aPL with cells is predominantly via cell surface receptors. Several receptors have been implicated in aPL signalling including TLRs 2 and 4, which have lipid-based ligands, as well as lipoprotein receptors with which $\beta_{2} \mathrm{GPI}$ interacts. The ability of aPL to activate these TLRs may arise because $\beta_{2} \mathrm{GPI}$ shares molecular mimicry with bacterial products such as lipopolysaccharide (Blank \& Shoenfeld 2004, Sorice et al. 2007). Interactions of aPL with endothelial cells have been shown to be mediated by TLR4, and when they have invaded the spiral arteries, extravillous trophoblasts take on the functions and some feature of endothelial cells. Although the effects of aPL on extravillous trophoblasts have been shown to be mediated by TLR4 (Mulla et al. 2009), there is some disagreement as to whether the intracellular signalling is mediated primarily by the MyD88 or TRIM/TRAF pathways (Poulton et al. 2015). It has also recently been shown that aPL are rapidly taken up specifically into the syncytiotrophoblast by a receptor-mediated mechanism. The receptor responsible for this uptake has not yet been specifically identified; however, it was shown that this was not typical antibody transport and was not mediated by an Fc-receptor. The receptor appeared to be a member of the LDL receptor family, as its effects were blocked by receptor-associated protein (Viall et al. 2013). Indeed, in other work, the LDL receptor family member ApoER2 has been shown to mediate changes in trophoblast function and pregnancy complications induced by aPL (Ulrich et al. 2016).

\section{Lessons from animal models}

The pathogenicity of aPL in pregnancy has been well established in murine models of APS. Infusion of aCL derived from humans or mice into pregnant mice resulted in lower fecundity, increased resorption of embryos, reduced number of embryos per pregnancy and lower fetal and placental weight compared with controls in several studies (Gharavi et al. 1989, Blank et al. 1991, Suzuki et al. 1996). Mice injected with aPL show signs of placental thrombosis, decidual necrosis and infarction, which may play a role in fetal loss and pregnancy failure (Branch et al. 1990). Mice in which $\beta_{2} \mathrm{GPI}$ has been knocked out are fertile but have reduced fetal and placental weights, indicating that, while necessary for optimal fetal growth and development, $\beta_{2} \mathrm{GPI}$ is not essential to pregnancy, at least in mice (Robertson et al. 2004).

The mechanism by which aPL induce fetal demise in mice has been clearly established in series of elegant experiments (Holers et al. 2002, Girardi et al. 2003, 2004). Using a combination of knockout mice, recombinant proteins and neutralising antibodies, it has been shown that aPL activate the complement cascade resulting in the recruitment of neutrophils to the implantation site. These neutrophils, in conjunction with the complement system and the pro-inflammatory protein tissue factor, result in the destruction of affected embryos. Complement component $\mathrm{C} 3$, deposited in the remains of implantation sites, is a marker of this process. Although this mechanism is clearly established in mice, it is much less clear how much of a role the complement system plays in fetal demise in women. There is limited evidence for deposition of $\mathrm{C} 3$ in the placentae of women with aPL (Out et al. 1991, Viall \& Chamley 2015). However, one study has reported increased complement deposition in the trophoblast cytoplasm (C4d and C3b), trophoblastic cell and basement membrane (C4d), and extravillous trophoblasts (C4d) of patients with aPL, compared with control patients (Shamonki et al. 2007).

The complement cascade has also been associated with the development of pre-eclampsia, which is one of the clinical manifestations of obstetrics APS (Haeger et al. 1992). One recent prospective study demonstrated that seven out of 40 patients who had aPL and developed pre-eclampsia displayed mutations in complement regulatory proteins, suggesting that complement activation may play a role in initiating pre-eclampsia in the presence of aPL in some women (Salmon et al. 2011). The mechanistic differences in how aPL induce obstetric disease between mice and women may relate to the quite different anatomical structures of 
the materno-fetal interface between these species and also to the mechanisms and proteins responsible for the regulation of complement activation that differs at the materno-fetal interface in mice and women. In mice, a single molecule, CRRY1, is the major regulator of complement, whereas in women, three proteins CD46, CD55 and CD59 are present to prevent complement activation.

\section{Treatments}

Owing to the theory that aPL cause fetal loss mainly by inducing thrombosis and placental infarction, heparin has been utilized to treat women with APS. However, as most placentae of women with aPL do not show signs of thrombosis, heparin likely acts via another mechanism to prevent fetal loss (Tong et al. 2015). In vitro studies suggest that heparin prevents the binding of polyclonal and monoclonal aPL to trophoblasts and may inhibit the binding of $\beta_{2} \mathrm{GPI}$ to anionic phospholipids. Heparin may also exert a protective effect on trophoblasts by antagonizing the effect of aPL on trophoblast death, syncytialization, complement activation and inflammation (Di Simone et al. 1997, Bose et al. 2004, Girardi et al. 2004, Mulla et al. 2009, 2010). That heparin acts via a non-anticoagulant mechanism is also supported by the observation that clinical trials employing unfractioned heparin show a protective effect against $\mathrm{aPL}$, whereas trials employing low-molecular-weight heparin (LMWH) have less convincing results (Farquharson et al. 2002, Rai \& Regan 2002, Noble et al. 2005, de Jesus et al. 2014). In a recent meta-analysis, Ziakas et al. concluded that heparin plus LDA is not more effective than LDA alone in treating women with APS-related fetal deaths but at least one of the trials included in that meta-analysis included a mixed population of patients only some of whom had APS (Ziakas et al. 2010). Moreover, a number of studies have shown that heparin promotes the placental release of sFlt1 (Carroll et al. 2011, Rosenberg et al. 2011), an anti-angiogenic factor associated with pre-eclampsia (Maynard et al. 2003). However, in vitro studies indicate that vitamin $\mathrm{D}$ may reverse this $\mathrm{LMWH}$-induced trophoblast sFlt1 secretion (Gysler et al. 2015). The effects of different therapies used in clinical trials to treat women with obstetric APS have been systematically reviewed (White et al. 2004). Ten randomized or quasirandomized, controlled trials were assessed. Aspirin alone (three trials) had no effect on pregnancy loss, whereas heparin in combination with aspirin (two trials, 140 patients) reduced pregnancy loss in women with APS by $54 \%$. Prednisone in combination with aspirin increased prematurity but did not reduce fetal loss at high dose. Low-dose prednisone administered up to 14 weeks of gestation to women with previous aPLrelated pregnancy loss increased the live birth rate from
4 to $61 \%$, and this option warrants further assessment (Bramham et al. 2011).

Anti-malarial and anti-inflammatory drugs have also been utilized to prevent APS-mediated fetal loss. The effects of hydroxychloroquine on trophoblasts treated with aPL have been investigated in six studies (Tong et al. 2015). Hydroxychloroquine has been found to antagonize the effects of aPL on annexin A5 and coagulation on the surface of trophoblasts. It also prevents the effects of aPL on trophoblast migration, invasion, hCG secretion and fusion (Albert et al. 2014). Chloroquine also reduces aPL internalization in firsttrimester placental explants (Albert et al. 2014). Antiinflammatory drugs such as indomethacin antagonize trophoblast prostacyclin and thromboxane production, whereas betamethasone prevents the effects of aPL on hCG secretion. IL3 has been used in some studies to prevent fetal loss and appears to reverse the effect of aPL on syncytialization, trophoblast invasion and hCG secretion (Chamley et al. 2001).

Although pravastatin reduces fetal loss in a murine model of APS, its effect on humans is unknown. In vitro, pravastatin had no effect on aPL-mediated changes in trophoblast inflammatory mediators and invasion and may, therefore, not be as beneficial in human pregnancies complicated by APS (Odiari et al. 2012). However, preliminary studies suggest that it might be useful at stabilizing the clinical and biochemical features of preterm pre-eclampsia (Brownfoot et al. 2015). That said, in a case study, a patient with a history of pre-eclampsia, thrombosis, and APS, presenting with pre-eclampsia at 23 weeks of gestation in her second pregnancy was treated with pravastatin, and this resulted in marked clinical improvement and successful pregnancy outcome (Lefkou et al. 2014). There is a clear need for better therapeutic approaches and alternative explanations for why existing therapies, such as heparin and LDA, appear to have positive effects in pregnancies affected by aPL. In vitro, as well as in vivo, studies may help to inform us. For example, in a recent study, the aspirin-triggered lipoxin, 15-epi-lipoxin A4, reversed the negative effect of aPL and sera from APS patients on trophoblast migration and trophoblast-endothelial cell interactions (Alvarez et al. 2015).

\section{Conclusions}

Although there have been great advances in our understanding of $\mathrm{aPL}$, the mechanisms by which they lead to obstetric disease still remain unclear. Standardization of detection assays and better study design will allow for directly comparable studies and better reproducibility between studies. It has become clear that aPL interact directly with all populations of human trophoblasts, adversely altering their function, although murine models confirm that these antibodies 
are pathogenic and not just markers of a disease process. Current therapies, such as heparin, have been applied apparently successfully to prevent recurrent miscarriage caused by aPL; however, the evidence is not entirely conclusive and the optimal therapy to prevent the poor obstetric outcomes associated with these antibodies remains to be determined. Ongoing and future research will hopefully identify the pathways by which aPL exert their detrimental effects during pregnancy to allow the identification of better therapeutic approaches and predictors of pregnancy outcomes.

\section{Declaration of interest}

The authors declare that there is no conflict of interest that could be perceived as prejudicing the impartiality of the review.

\section{Funding}

This review did not receive any specific grant from any funding agency in the public, commercial or not-for-profit sector.

\section{References}

Abrahams VM 2009 Mechanisms of antiphospholipid antibody-associated pregnancy complications. Thrombosis Research 124 521-525. (doi:10.1016/j.thromres.2009.07.011)

Albert CR, Schlesinger WJ, Viall CA, Mulla MJ, Brosens JJ, Chamley LW \& Abrahams VM 2014 Effect of hydroxychloroquine on antiphospholipid antibody-induced changes in first trimester trophoblast function. American Journal of Reproductive Immunology 71 154-164. (doi:10.1111/aji.2014.71.issue-2)

Alvarez AM, Mulla MJ, Chamley LW, Cadavid AP \& Abrahams VM 2015 Aspirin-triggered lipoxin prevents antiphospholipid antibody effects on human trophoblast migration and endothelial cell interactions. Arthritis \& Rheumatology 67 488-497. (doi:10.1002/art.v67.2)

Andreoli L, Chighizola CB, Nalli C, Gerosa M, Borghi MO, Pregnolato F, Grossi C, Zanola A, Allegri F, Norman GL et al. 2015 Clinical characterization of antiphospholipid syndrome by detection of IgG antibodies against $\beta 2$-glycoprotein i domain 1 and domain 4/5: ratio of anti-domain 1 to anti-domain $4 / 5$ as a useful new biomarker for antiphospholipid syndrome. Arthritis \& Rheumatology 67 2196-2204. (doi:10.1002/art.39187)

Asherson R \& Cervera R 1993 Anticardiolipin antibodies, chronic biologic false-positive tests for syphilis and other antiphospholipid antibodies. In Duboi's Systemic Lupus Erythematosus, pp 233-245. Eds DJ Wallace \& BH Hahn. Philadelphia, PA, USA: Lea \& Febiger.

Askelund K \& Chamley L 2011 Trophoblast deportation part I: review of the evidence demonstrating trophoblast shedding and deportation during human pregnancy. Placenta 32 716-723. (doi:10.1097/ MD.0000000000002382)

Atsumi T, leko M, Bertolaccini ML, Ichikawa K, Tsutsumi A, Matsuura E \& Koike T 2000 Association of autoantibodies against the phosphatidylserine-prothrombin complex with manifestations of the antiphospholipid syndrome and with the presence of lupus anticoagulant. Arthritis \& Rheumatology 43 1982-1993. (doi:10.1002/15290131(200009)43:9<1 982::AID-ANR9>3.0.CO;2-2)

Bakimer R, Fishman P, Blank M, Sredni B, Djaldetti M \& Shoenfeld Y 1992 Induction of primary antiphospholipid syndrome in mice by immunization with a human monoclonal anticardiolipin antibody (H-3). Journal of Clinical Investigation 89 1558-1563. (doi:10.1172/ JCl115749)

Bertolaccini ML, Amengual $O$, Atsumi T, Binder $W L$, de Laat B, Forastiero R, Kutteh WH, Lambert M, Matsubayashi $\mathbf{H}$, Murthy $\mathbf{V}$ et al. 2011 'Non-criteria' aPL tests: report of a task force and preconference workshop at the 13th International Congress on Antiphospholipid Antibodies, Galveston, TX, USA, April 2010. Lupus 20 191-205. (doi:10.1177/0961203310397082)

Blank M \& Shoenfeld Y 2004 Beta-2-glycoprotein-I, infections, antiphospholipid syndrome and therapeutic considerations. Clinical Immunology 112 190-199. (doi:10.1016/j.clim.2004.02.018)

Blank M, Cohen J, Toder V \& Shoenfeld Y 1991 Induction of antiphospholipid syndrome in naive mice with mouse lupus monoclonal and human polyclonal anti-cardiolipin antibodies. PNAS 883069 3073. (doi:10.1073/pnas.88.8.3069)

Blank M, Faden D, Tincani A, Kopolovic J, Goldberg I, Gilburd B, Allegri F, Balestrieri G, Valesini G \& Shoenfeld Y 1994 Immunization with anticardiolipin cofactor ( $\beta$-2-glycoprotein I) induces experimental antiphospholipid syndrome in naive mice. Journal of Autoimmunity 7 441-455. (doi:10.1006/jaut.1994.1032)

Bose P, Black S, Kadyrov M, Bartz C, Shlebak A, Regan L \& Huppertz B 2004 Adverse effects of lupus anticoagulant positive blood sera on placental viability can be prevented by heparin in vitro. American Journal of Obstetrics and Gynecology 191 2125-2131. (doi:10.1016/j. ajog.2004.05.014)

Bramham K, Thomas M, Nelson-Piercy C, Khamashta M \& Hunt BJ 2011 First-trimester low-dose prednisolone in refractory antiphospholipid antibody-related pregnancy loss. Blood 117 6948-6951. (doi:10.1182/ blood-2011-02-339234)

Branch DW, Andres R, Digre KB, Rote NS \& Scott JR 1989 The association of antiphospholipid antibodies with severe preeclampsia. Obstetrics and Gynecology 73 541-545.

Branch DW, Dudley DJ, Mitchell MD, Creighton KA, Abbott TM, Hammond EH \& Daynes RA 1990 Immunoglobulin G fractions from patients with antiphospholipid antibodies cause fetal death in BALB/C mice: a model for autoimmune fetal loss. American Journal of Obstetrics and Gynecology 163 210-216. (doi:10.1016/S0002-9378(11)90700-5)

Brownfoot FC, Tong S, Hannan NJ, Binder NK, Walker SP, Cannon P, Hastie R, Onda K \& Kaitu'u-Lino TJ 2015 Effects of pravastatin on human placenta, endothelium, and women with severe preeclampsia. Hypertension 66 687-697 (discussion 445). (doi:10.1161/ HYPERTENSIONAHA.115.05445)

Buckingham KL \& Chamley LW 2009 A critical assessment of the role of antiphospholipid antibodies in infertility. Journal of Reproductive Immunology 80 132-145. (doi:10.1093/humrep/deq100)

Carroll TY, Mulla MJ, Han CS, Brosens JJ, Chamley LW, Giles I, Pericleous C, Rahman A, Sfakianaki AK, Paidas MJ et al. 2011 Modulation of trophoblast angiogenic factor secretion by antiphospholipid antibodies is not reversed by heparin. American Journal of Reproductive Immunology 66 286-296. (doi:10.1111/aji.2011.66.issue-4)

Cervera R, Serrano R, Pons-Estel GJ, Ceberio-Hualde L, Shoenfeld Y, de Ramon E, Buonaiuto V, Jacobsen S, Zeher MM, Tarr T et al. 2015 Morbidity and mortality in the antiphospholipid syndrome during a 10-year period: a multicentre prospective study of 1000 patients. Annals of the Rheumatic Diseases 74 1011-1018. (doi:10.1136/ annrheumdis-2013-204838)

Chamley LW 1997 Antiphospholipid antibodies or not? The role of $\beta 2$ glycoprotein 1 in autoantibody-mediated pregnancy loss. Journal of Reproductive Immunology 36 123. (doi:10.1016/S01650378(97)00063-6)

Chamley LW, Pattison NS \& McKay EJ 1993 Elution of anticardiolipin antibodies and their cofactor $\beta 2$-glycoprotein 1 from the placentae of patients with a poor obstetric history. Journal of Reproductive Immunology 25 209-220. (doi:10.1067/mob.2000.106754)

Chamley LW, Konarkowska B, Duncalf AM, Mitchell MD \& Johnson PM 2001 Is interleukin-3 important in antiphospholipid antibody-mediated pregnancy failure? Fertility and Sterility 76 700-706. (doi:10.1016/ S0015-0282(01)01984-7)

Chen Q, Viall C, Kang Y, Liu B, Stone P \& Chamley L 2009 Antiphospholipid antibodies increase non-apoptotic trophoblast shedding: a contribution to the pathogenesis of pre-eclampsia in affected women? Placenta 30 767-773. (doi:10.1016/j.placenta.2009.06.008)

Chen Q, Guo F, Jin HY, Lau S, Stone P \& Chamley L 2012 Phagocytosis of apoptotic trophoblastic debris protects endothelial cells against activation. Placenta 33 548-553. (doi:10.1016/j.placenta.2012.03.007)

Ding X, Yang Z, Han Y \& Yu H 2014 Long-chain fatty acid oxidation changes in a $\beta 2$ glycoprotein I-induced preeclampsia-like mouse model. Placenta 35 392-397. (doi:10.1016/j.placenta.2014.03.013) 
Di Simone N, Ferrazzani S, Castellani R, De Carolis S, Mancuso S \& Caruso A 1997 Heparin and low-dose aspirin restore placental human chorionic gonadotrophin secretion abolished by antiphospholipid antibody-containing sera. Human Reproduction 12 2061-2065. (doi:10.1093/humrep/12.9.2061)

Di Simone N, Caliandro D, Castellani R, Ferrazzani S \& Caruso A 2000a Interleukin-3 and human trophoblast: in vitro explanations for the effect of interleukin in patients with antiphospholipid antibody syndrome. Fertility and Sterility 73 1194-1200. (doi:10.1016/S00150282(00)00533-1)

Di Simone N, Meroni PL, de Papa N, Raschi E, Caliandro D, De Carolis CS, Khamashta MA, Atsumi T, Hughes GR \& Balestrieri G $2000 b$ Antiphospholipid antibodies affect trophoblast gonadotropin secretion and invasiveness by binding directly and through adhered B2-glycoprotein I. Arthritis \& Rheumatology 43 140. (doi:10.1002/ (ISSN)1529-0131)

Di Simone N, Castellani R, Caliandro D \& Caruso A 2001 Monoclonal anti-annexin $\mathrm{V}$ antibody inhibits trophoblast gonadotropin secretion and induces syncytiotrophoblast apoptosis. Biology of Reproduction $\mathbf{6 5}$ 1766. (doi:10.1016/S0303-7207(01)00648-7)

Di Simone N, Castellani R, Caliandro D \& Caruso A 2002 Antiphospholid antibodies regulate the expression of trophoblast cell adhesion molecules. Fertility and Sterility 77 805. (doi:10.1016/S0303-7207(01)00648-7)

Di Simone N, Castellani R, Raschi E, Borghi MO, Meroni PL \& Caruso A 2006 Anti- $\beta$ - 2 glycoprotein I antibodies affect Bcl-2 and Bax trophoblast expression without evidence of apoptosis. Annals of the New York Academy of Sciences 1069 364-376. (doi:10.1002/art.27361)

Di Simone N, Marana R, Castellani R, Di Nicuolo F, D'Alessio MC, Raschi E, Borghi MO, Chen PP, Sanguinetti M, Caruso A et al. 2010 Decreased expression of heparin-binding epidermal growth factor-like growth factor as a newly identified pathogenic mechanism of antiphospholipidmediated defective placentation. Arthritis \& Rheumatology 621504 1512. (doi:10.1002/art.27361)

Drakeley AJ, Quenby S \& Farquharson RG 1998 Mid-trimester loss appraisal of a screening protocol. Human Reproduction 13 1975-1980. (doi:10.1093/humrep/13.7.1975)

Duckitt K \& Harrington D 2005 Risk factors for pre-eclampsia at antenatal booking: systematic review of controlled studies. BMJ 330 565-567. (doi:10.1136/bmj.38380.674340.E0)

Faden D, Tincani A, Tanzi P, Spatola L, Lojacono A, Tarantini M \& Balestrieri G 1997 Anti- $\beta 2$ glycoprotein I antibodies in a general obstetric population: preliminary results on the prevalence and correlation with pregnancy outcome. Anti- $\beta 2$ glycoprotein I antibodies are associated with some obstetrical complications, mainly preeclampsia-eclampsia. European Journal of Obstetrics, Gynecology, and Reproductive Biology 7337 (doi:10.1016/S0301-2115(97)02736-X)

Farquharson RG, Quenby S \& Greaves M 2002 Antiphospholipid syndrome in pregnancy: a randomized, controlled trial of treatment. Obstetrics and Gynecology 100 408-413. (doi:10.1056/NEJMoa1504927)

Forastiero R, Papalardo E, Watkins M, Nguyen H, Quirbach C, Jaskal K, Kast M, Teodorescu M, Lakos G, Binder W et al. 2014 Evaluation of different immunoassays for the detection of antiphospholipid antibodies: report of a wet workshop during the 13th International Congress on Antiphospholipid Antibodies. Clinica Chimica Acta 428 99-105. (doi:10.1016/j.cca.2013.11.009)

Fournier T, Guibourdenche J \& Evain-Brion D 2015 Review: hCGs: different sources of production, different glycoforms and functions. Placenta 36 (Suppl 1) S60-S65. (doi:10.1016/j.placenta.2015.02.002)

Galarza-Maldonado C, Kourilovitch MR, Perez-Fernandez OM, Gaybor M, Cordero C, Cabrera S \& Soroka NF 2012 Obstetric antiphospholipid syndrome. Autoimmunity Reviews 11 288-295. (doi:10.1016/j. autrev.2011.10.006)

Galli M 2012 Interpretation and recommended testing for antiphospholipid antibodies. Seminars in Thrombosis and Hemostasis 38 348-352. (doi: 10.1055/s-0032-1304716)

Gharavi AE, Harris EN, Asherson RA \& Hughes GR 1987 Anticardiolipin antibodies: isotype distribution and phospholipid specificity. Annals of the Rheumatic Diseases 46 1-6. (doi:10.1136/ard.46.8.605)

Gharavi AE, Mellors RC \& Elkon KB 1989 IgG anti-cardiolipin antibodies in murine lupus. Clinical and Experimental Immunology 78 233-238.

Ginsberg JS, Wells PS, Brill-Edwards P, Donovan D, Moffatt K, Johnston M, Stevens P \& Hirsh J 1995 Antiphospholipid antibodies and venous thromboembolism. Blood 86 3685-3691.
Girardi G, Berman J, Redecha P, Spruce L, Thurman JM, Kraus D, Hollmann TJ, Casali P, Caroll MC, Wetsel RA et al. 2003 Complement C5a receptors and neutrophils mediate fetal injury in the antiphospholipid syndrome. Journal of Clinical Investigation 112 16441654. (doi:10.1172/JCI200318817)

Girardi G, Redecha P \& Salmon JE 2004 Heparin prevents antiphospholipid antibody-induced fetal loss by inhibiting complement activation. Nature Medicine 10 1222-1226. (doi:10.1182/blood-2009-01-199117)

Gysler SM, Mulla MJ, Stuhlman M, Sfakianaki AK, Paidas MJ, Stanwood NL, Gariepy A, Brosens JJ, Chamley LW \& Abrahams VM 2015 Vitamin D reverses aPL-induced inflammation and $\mathrm{LMWH}$-induced sFlt-1 release by human trophoblast. American Journal of Reproductive Immunology 73 242-250. (doi:10.1111/aji.2015.73.issue-3)

Haeger M, Unander M, Norder-Hansson B, Tylman M \& Bengtsson A 1992 Complement, neutrophil, and macrophage activation in women with severe preeclampsia and the syndrome of hemolysis, elevated liver enzymes, and low platelet count. Obstetrics and Gynecology $\mathbf{7 9}$ $19-26$.

Hirakawa E, Saito K, Hirata S, Atsumi T, Koike T \& Tanaka Y 2012 A case of catastrophic antiphospholipid antibody syndrome complicated with systemic lupus erythematosus, double positive for anti-cardiolipin $/ \beta(2)$ glycoprotein I and anti-phosphatidylserine/prothrombin autoantibodies. Modern Rheumatology 22 769-773. (doi:10.3109/s10165-011-0563-z)

Holers VM, Girardi G, Mo L, Guthridge JM, Molina H, Pierangeli SS, Espinola R, Xiaowei LE, Mao D, Vialpando CG et al. 2002 Complement C3 activation is required for antiphospholipid antibody-induced fetal loss. Journal of Experimental Medicine 195 211-220. (doi:10.1084/ jem.200116116)

Horkko S, Miller E, Dudl E, Reaven P, Curtiss LK, Zvaifler NJ, Terkeltaub R, Pierangeli SS, Branch DW, Palinski W et al. 1996 Antiphospholipid antibodies are directed against epitopes of oxidized phospholipids. Recognition of cardiolipin by monoclonal antibodies to epitopes of oxidized low density lipoprotein. Journal of Clinical Investigation $\mathbf{9 8}$ 815-825. (doi:10.1172/JCI118854)

Ichikawa G, Yamamoto T, Chishima F, Nakamura A, Kuno S, Murase T \& Suzuki M 2011 Effects of anti- $\beta 2$-glycoprotein I antibody on PIGF, VEGF and sVEGFR1 production from cultured choriocarcinoma cell line. Journal of Obstetrics and Gynaecology Research 37 1076-1083. (doi:10.1111/jog.2011.37.issue-8)

Iverson GM, Victoria EJ \& Marquis DM 1998 Anti- $\beta 2$ glycoprotein I ( $\left.\beta_{2} \mathrm{GPI}\right)$ autoantibodies recognize an epitope on the first domain of $\beta_{2}$ GPI. PNAS 95 15542-15546. (doi:10.1016/j.cccn.2004.01.008)

Iwasawa Y, Kawana K, Fujii T, Schust DJ, Nagamatsu T, Kawana Y, Sayama S, Miura S, Matsumoto J, Adachi K et al. 2012 A possible coagulation-independent mechanism for pregnancy loss involving $\beta(2)$ glycoprotein 1-dependent antiphospholipid antibodies and CD1d. American Journal of Reproductive Immunology 67 54-65. (doi:10.1111/ aji.2011.67.issue-1)

de Jesus GR, Agmon-Levin N, Andrade CA, Andreoli L, Chighizola CB, Porter TF, Salmon J, Silver RM, Tincani A \& Branch DW 2014 14th International Congress on Antiphospholipid Antibodies Task Force report on obstetric antiphospholipid syndrome. Autoimmunity Reviews 13 795-813. (doi:10.1016/j.autrev.2014.02.003)

Katano K, Aoki A, Sasa H, Ogasawara M, Matsuura E \& Yagami Y 1996 beta 2-Glycoprotein I-dependent anticardiolipin antibodies as a predictor of adverse pregnancy outcomes in healthy pregnant women. Human Reproduction 11 509-512. (doi:10.1093/HUMREP/11.3.509)

Katsuragawa H, Kanzaki H, Inoue T, Hirano T, Mori T \& Rote NS 1997 Monoclonal antibody against phosphatidylserine inhibits in vitro human trophoblastic hormone production and invasion. Biology of Reproduction 56 50-58. (doi:10.1095/biolreprod56.1.50)

Krikun G, Lockwood C, Wu X, Zhou X, Guller S, Calandri C, Guha A, Nemerson Y \& Rand J 1994 The expression of the placental anticoagulant protein, annexin $\mathrm{V}$, by villous trophoblasts: immunolocalization and in vitro regulation. Placenta 15601. (doi:10.1016/S0143-4004(05)80407-2)

Lakasing L, Campa J, Poston R, Khamashta M \& Poston L 1999 Normal expression of tissue factor, thrombomodulin, and annexin $\mathrm{V}$ in placentas from women with antiphospholipid syndrome. American Journal of Obstetrics and Gynecology 181 180. (doi:10.1016/S00029378(99)70457-6)

de Laat HB, Derksen RH, Urbanus RT, Roest M \& de Groot PG 2004 beta 2-Glycoprotein I-dependent lupus anticoagulant highly correlates with 
thrombosis in the antiphospholipid syndrome. Blood 104 3598-3602. (doi:10.1182/blood-2004-03-1107)

de Laat B, Wu X, van Lummel M, Derksen R, de Groot P \& Rand J 2007 Correlation between antiphospholipid antibodies that recognize domain I of $\beta 2$-glycoprotein I and a reduction in the anticoagulant activity of annexin A5. Blood 109 1490. (doi:10.1182/blood-2006-07-030148)

de Laat B, Pengo V, Pabinger I, Musial J, Voskuyl A, Bultink I, Ruffatti A, Rozman B, Kveder T \& de Moerloose P 2009 The association between circulating antibodies against domain I of $\beta 2$-glycoprotein I and thrombosis: an International Multicenter Study. Journal of Thrombosis and Haemostasis 7 1767. (doi:10.1111/jth.2009.7.issue-11)

Lefkou E, Mamopoulos A, Fragakis N, Dagklis T, Vosnakis C, Nounopoulos E, Rousso D \& Girardi G 2014 Clinical improvement and successful pregnancy in a preeclamptic patient with antiphospholipid syndrome treated with pravastatin. Hypertension 63 e118-e119. (doi:10.1161/ HYPERTENSIONAHA.114.03115)

Love PE \& Santoro SA 1990 Antiphospholipid antibodies: anticardiolipin and the lupus anticoagulant in systemic lupus erythematosus (SLE) and in non-SLE disorders. Prevalence and clinical significance. Annals of Internal Medicine 112 682-698. (doi:10.1073/pnas.1520245113)

Marchetti T, Ruffatti A, Wuillemin C, de Moerloose P \& Cohen M 2014 Hydroxychloroquine restores trophoblast fusion affected by antiphospholipid antibodies. Journal of Thrombosis and Haemostasis 12 910-920. (doi:10.1111/jth.2014.12.issue-6)

Mayhew TM 2008 Taking tissue samples from the placenta: an illustration of principles and strategies. Placenta 29 1-14. (doi:10.1016/ j.placenta.2007.05.010)

Maynard SE, Min JY, Merchan J, Lim KH, Li J, Mondal S, Libermann TA, Morgan JP, Sellke FW \& Stillman IE 2003 Excess placental soluble fmslike tyrosine kinase 1 (sFlt1) may contribute to endothelial dysfunction, hypertension, and proteinuria in preeclampsia. Journal of Clinical Investigation 111 649-658. (doi:10.1172/JCI17189)

McIntyre JA, Wagenknecht DR \& Sugi T 1997 Phospholipid binding plasma proteins required for antiphospholipid antibody detection - an overview. American Journal of Reproductive Immunology 37 101-110. (doi:10.3109/08916934.2015.1008464)

Miyakis S, Lockshin MD, Atsumi T, Branch DW, Brey RL, Cervera R, Derksen RH, de Groot PG, Koike T, Meroni PL et al. 2006 International consensus statement on an update of the classification criteria for definite antiphospholipid syndrome (APS). Journal of Thrombosis and Haemostasis 4 295-306. (doi:10.1111/jth.2006.4.issue-2)

Mulla MJ, Brosens JJ, Chamley LW, Giles I, Pericleous C, Rahman A, Joyce SK, Panda B, Paidas MJ \& Abrahams VM 2009 Antiphospholipid antibodies induce a pro-inflammatory response in first trimester trophoblast via the TLR4/MyD88 pathway. American Journal of Reproductive Immunology 62 96-111. (doi:10.1111/j.1600-0897.2009.00717.x)

Mulla MJ, Myrtolli K, Brosens JJ, Chamley LW, Kwak-Kim JY, Paidas MJ \& Abrahams VM 2010 Antiphospholipid antibodies limit trophoblast migration by reducing IL-6 production and STAT3 activity. American Journal of Reproductive Immunology 63 339-348. (doi:10.1111/j.16000897.2009.00805.x)

Mulla MJ, Salmon JE, Chamley LW, Brosens JJ, Boeras CM, Kavathas PB \& Abrahams VM 2013 A role for uric acid and the Nalp3 inflammasome in antiphospholipid antibody-induced IL-1 $\beta$ production by human first trimester trophoblast. PLOS ONE 8 e65237. (doi:10.1371/journal. pone.0065237)

Noble LS, Kutteh WH, Lashey N, Franklin RD \& Herrada J 2005 Antiphospholipid antibodies associated with recurrent pregnancy loss: prospective, multicenter, controlled pilot study comparing treatment with low-molecular-weight heparin versus unfractionated heparin. Fertility and Sterility 83 684-690. (doi:10.1016/j.fertnstert.2004.11.002)

Odiari E, Mulla M, Sfakianaki A, Paidas M, Stanwood N, Gariepy A, Brosens J, Chamley L \& Abrahams V 2012 Pravastatin does not prevent antiphospholipid antibody-mediated changes in human first trimester trophoblast function. Human Reproduction 27 2933-2940. (doi:10.1093/humrep/des288)

Oosting JD, Derksen RH, Bobbink IW, Hackeng TM, Bouma BN \& de Groot PG 1993 Antiphospholipid antibodies directed against a combination of phospholipids with prothrombin, protein $\mathrm{C}$, or protein S: an explanation for their pathogenic mechanism? Blood $\mathbf{8 1}$ 2618-2625.

Ornoy A, Yacobi S, Matalon ST, Blank M, Blumenfeld Z, Miller RK \& Shoenfeld Y 2003 The effects of antiphospholipid antibodies obtained from women with SLE/APS and associated pregnancy loss on rat embryos and placental explants in culture. Lupus 12 573-578. (doi:10.1191/096 1203303lu405oa)

Out HJ, Kooijman CD, Bruinse HW \& Derksen RH 1991 Histopathological findings in placentae from patients with intra-uterine fetal death and anti-phospholipid antibodies. European Journal of Obstetrics, Gynecology, and Reproductive Biology 41 179-186. (doi:10.1016/00282243(91)90021-C)

Pangborn MC 1941 A new serologically active phospholipid from beef heart. Proceedings of the Society of Experimental Biology 48 484-486.

Pantham P, Rosario R, Chen Q \& Chamley L 2012 Transcriptomic analysis of placenta affected by antiphospholipid antibodies: following the TRAIL of trophoblast death. Journal of Reproductive Immunology 94 151-154. (doi:10.1016/j.jri.2012.03.487)

Pantham P, Viall CA, Chen Q, Kleffmann T, Print CG \& Chamley LW 2015a Antiphospholipid antibodies bind syncytiotrophoblast mitochondria and alter the proteome of extruded syncytial nuclear aggregates. Placenta 36 1463-1473. (doi:10.1016/j.placenta.2015.10.006)

Pantham P, Heazell AE, Mullard G, Begley P, Chen Q, Brown M, Dunn WB \& Chamley LW 2015b Antiphospholipid antibodies alter cell-death-regulating lipid metabolites in first and third trimester human placentae. American Journal of Reproductive Immunology 74 181-199. (doi:10.1111/aji.12387)

Pijnenborg R, Vercruysse L \& Hanssens M 2006 The uterine spiral arteries in human pregnancy: facts and controversies. Placenta 27 939-958. (doi:10.1016/j.placenta.2013.01.002)

Poulton K, Ripoll VM, Pericleous C, Meroni PL, Gerosa M, loannou Y, Rahman A \& Giles IP 2015 Purified IgG from patients with obstetric but not IgG from non-obstetric antiphospholipid syndrome inhibit trophoblast invasion. American Journal of Reproductive Immunology 73 390-401. (doi:10.1111/aji.2015.73.issue-5)

Quenby S, Mountfield S, Cartwright JE, Whitley GS, Chamley L \& Vince G 2005 Antiphospholipid antibodies prevent extravillous trophoblast differentiation. Fertility and Sterility 83 691-698. (doi:10.1016/ j.fertnstert.2004.07.978)

Rai R \& Regan L 2002 Antiphospholipid syndrome in pregnancy: a randomized, controlled trial of treatment. Obstetrics and Gynecology 1001354.

Rand J \& Wu X 1999 Antibody-mediated disruption of the annexin-V antithrombotic shield: a new mechanism for thrombosis in the antiphospholipid syndrome. Thrombosis and Haemostasis 82649.

Rand J, Wu X, Guller S, Gil J, Guha A, Scher J \& Lockwood C 1994 Reduction of annexin- $V$ (placental anticoagulant protein-I) on placental villi of women with antiphospholipid antibodies and recurrent spontaneous abortion. American Journal of Obstetrics and Gynecology 171 1566. (doi:10.1016/0002-9378(94)90403-0)

Rand J, Wu X, Guller S, Scher J, Andree H \& Lockwood C 1997 Antiphospholipid immunoglobulin G antibodies reduce annexin-V levels on syncytiotrophoblast apical membranes and in culture media of placental villi. American Journal of Obstetrics and Gynecology 177918. (doi:10.1016/S0002-9378(97)70294-1)

Rand J, Wu X, Andree H, Ross J, Rusinova E, Gascon-Lema M, Calandri C \& Harpel P 1998 Antiphospholipid antibodies accelerate plasma coagulation by inhibiting annexin- $\mathrm{V}$ binding to phospholipids: a "lupus procoagulant" phenomenon. Blood 921652.

Rand JH, Wu XX, Quinn AS, Chen PP, McCrae KR, Bovill EG \& Taatjes DJ 2003 Human monoclonal antiphospholipid antibodies disrupt the annexin A5 anticoagulant crystal shield on phospholipid bilayers: evidence from atomic force microscopy and functional assay. American Journal of Pathology 163 1193. (doi:10.1016/S0002-9440(10)63479-7)

Rand J, Wu X, Lapinski R, van Heerde W, Reutelingsperger C, Chen P \& Ortel T 2004 Detection of antibody-mediated reduction of annexin A5 anticoagulant activity in plasmas of patients with the antiphospholipid syndrome. Blood 104 2783. (doi:10.1182/blood-2004-01-0203)

Rand J, Arslan A, Wu X, Wein R, Mulholland J, Shah M, van Heerde W, Reutelingsperger C, Lockwood C \& Kuczynski E 2006 Reduction of circulating annexin A5 levels and resistance to annexin A5 anticoagulant activity in women with recurrent spontaneous pregnancy losses. American Journal of Obstetrics and Gynecology 194 182. (doi:10.1016/j. ajog.2005.05.034)

Robertson SA, Roberts CT, van Beijering E, Pensa K, Sheng Y, Shi T \& Krilis SA 2004 Effect of $\beta 2$-glycoprotein I null mutation on reproductive outcome and antiphospholipid antibody-mediated pregnancy pathology 
in mice. Molecular Human Reproduction 10 409-416. (doi:10.1093/ molehr/gah058)

Rodriguez-Garcia V, Ioannou Y, Fernandez-Nebro A, Isenberg DA \& Giles IP 2015 Examining the prevalence of non-criteria anti-phospholipid antibodies in patients with anti-phospholipid syndrome: a systematic review. Rheumatology 54 2042-2050. (doi:10.1093/rheumatology/kev226)

Roggenbuck D, Egerer $K$, von Landenberg P, Hiemann R, Feist E, Burmester GR \& Dorner T 2012 Antiphospholipid antibody profiling: time for a new technical approach? Autoimmunity Reviews 11 821-826. (doi:10.1016/j.autrev.2012.02.016)

Rosenberg VA, Buhimschi IA, Lockwood CJ, Paidas MJ, Dulay AT, Ramma W, Abdel-Razeq SS, Zhao G, Ahmad S, Ahmed A et al. 2011 Heparin elevates circulating soluble fms-like tyrosine kinase- 1 immunoreactivity in pregnant women receiving anticoagulation therapy. Circulation 124 2543-2553. (doi:10.1161/CIRCULATIONAHA.111.046821)

Rote NS, Dostal-Johnson D \& Branch DW 1990 Antiphospholipid antibodies and recurrent pregnancy loss: correlation between the activated partial thromboplastin time and antibodies against phosphatidylserine and cardiolipin. American Journal of Obstetrics and Gynecology 163575 584. (doi:10.1006/clin.1993.1025)

Ruffatti A, Tonello M, Visentin MS, Bontadi A, Hoxha A, De Carolis S, Botta A, Salvi S, Nuzzo M, Rovere-Querini P et al. 2011 Risk factors for pregnancy failure in patients with anti-phospholipid syndrome treated with conventional therapies: a multicentre, case-control study. Rheumatology 50 1684-1689. (doi:10.1093/rheumatology/ker139)

Salafia C \& Cowchock F 1997 Placental pathology and antiphospholipid antibodies: a descriptive study. American Journal of Perinatology 14435. (doi:10.1016/j.placenta.2015.11.010)

Salmon JE, Heuser C, Triebwasser M, Liszewski MK, Kavanagh D, Roumenina L, Branch DW, Goodship T, Fremeaux-Bacchi V \& Atkinson JP 2011 Mutations in complement regulatory proteins predispose to preeclampsia: a genetic analysis of the PROMISSE cohort. PLoS Medicine 8 e1001013. (doi:10.1371/journal.pmed.1001013)

Schwartz N, Shoenfeld Y, Barzilai O, Cervera R, Font J, Blank M, Yacobi S, Patlas N, Cohen A, Mevorach D et al. 2007 Reduced placental growth and hCG secretion in vitro induced by antiphospholipid antibodies but not by anti-Ro or anti-La: studies on sera from women with SLE/PAPS. Lupus 16 110-120. (doi:10.1177/0961203306075741)

Shamonki JM, Salmon JE, Hyjek E \& Baergen RN 2007 Excessive complement activation is associated with placental injury in patients with antiphospholipid antibodies. American Journal of Obstetrics and Gynecology 196167 e161-e165. (doi:10.1016/j.ajog.2006.10.879)

Silver RM, Parker CB, Reddy UM, Goldenberg R, Coustan D, Dudley DJ, Saade GR, Stoll B, Koch MA, Conway D et al. 2013 Antiphospholipid antibodies in stillbirth. Obstetrics and Gynecology 122 641-657. (doi:10.1097/AOG.0b013e3182a1060e)

Sorice M, Longo A, Capozzi A, Garofalo T, Misasi R, Alessandri C, Conti F, Buttari B, Rigano R, Ortona E et al. 2007 Anti- $\beta 2$-glycoprotein I antibodies induce monocyte release of tumor necrosis factor $\alpha$ and tissue factor by signal transduction pathways involving lipid rafts. Arthritis \& Rheumatology 56 2687-2697. (doi:10.1002/(ISSN)1529-0131)

Suzuki T, Takabayashi K, Ichikawa K, Itou I, Ishiguro N, Yoshiki T \& Koike T 1996 Effects of monoclonal anticardiolipin antibody on pregnant mice. Journal of Rheumatology 23 83-86.
Tong M, Viall CA \& Chamley LW 2015 Antiphospholipid antibodies and the placenta: a systematic review of their in vitro effects and modulation by treatment. Human Reproduction Update 21 97-118. (doi:10.1093/ humupd/dmv006)

Ueki H, Mizushina T, Laoharatchatathanin T, Terashima R, Nishimura Y, Rieanrakwong D, Yonezawa T, Kurusu S, Hasegawa Y, Brachvogel B et al. 2012 Loss of maternal annexin A5 increases the likelihood of placental platelet thrombosis and fetal loss. Scientific Reports 2827.

Ulrich V, Gelber SE, Vukelic M, Sacharidou A, Herz J, Urbanus RT, de Groot PG, Natale DR, Harihara A, Redecha P et al. 2016 ApoE Receptor 2 mediates trophoblast dysfunction and pregnancy complications induced by antiphospholipid antibodies in mice. Arthritis \& Rheumatology 68 730-739. (doi:10.1002/art.39453)

Viall CA \& Chamley LW 2015 Histopathology in the placentae of women with antiphospholipid antibodies: a systematic review of the literature. Autoimmunity Reviews 14 446-471. (doi:10.1016/ j.placenta.2015.10.006)

Viall CA, Chen Q, Liu B, Hickey A, Snowise S, Salmon JE, Stone PR \& Chamley LW 2013 Antiphospholipid antibodies internalised by human syncytiotrophoblast cause aberrant cell death and the release of necrotic trophoblast debris. Journal of Autoimmunity 47 45-57. (doi:10.1016/ j.jaut.2013.08.005)

White CA, Johansson M, Roberts CT, Ramsay AJ \& Robertson SA 2004 Effect of interleukin-10 null mutation on maternal immune response and reproductive outcome in mice. Biology of Reproduction $70123-131$.

Wu R, Svenungsson E, Gunnarsson I, Haegerstrand-Gillis C, Andersson B, Lundberg I, Elinder LS \& Frostegard J 1999 Antibodies to adult human endothelial cells cross-react with oxidized low-density lipoprotein and $\beta 2$-glycoprotein I $\left(\beta_{2}\right.$-GPI) in systemic lupus erythematosus. Clinical and Experimental Immunology 115 561-566. (doi:10.1046/j.13652249.1999.00830.x)

Yacobi S, Ornoy A, Blumenfeld Z \& Miller RK 2002 Effect of sera from women with systemic lupus erythematosus or antiphospholipid syndrome and recurrent abortions on human placental explants in culture. Teratology 66 300-308. (doi:10.1191/0961203303lu405oa)

Yasuda M, Takakuwa K, Tokunaga A \& Tanaka K 1995 Prospective studies of the association between anticardiolipin antibody and outcome of pregnancy. Obstetrics and Gynecology 86 555-559. (doi:10.1016/ S0029-7844(95)80015-8)

Ziakas PD, Pavlou M \& Voulgarelis M 2010 Heparin treatment in antiphospholipid syndrome with recurrent pregnancy loss a systematic review and meta-analysis. Obstetrics and Gynecology 115 1256-1262. (doi:10.1016/j.ejogrb.2015.06.005)

Received 17 November 2015

First decision 8 January 2016

Revised manuscript received 11 February 2016

Accepted 16 February 2016 